
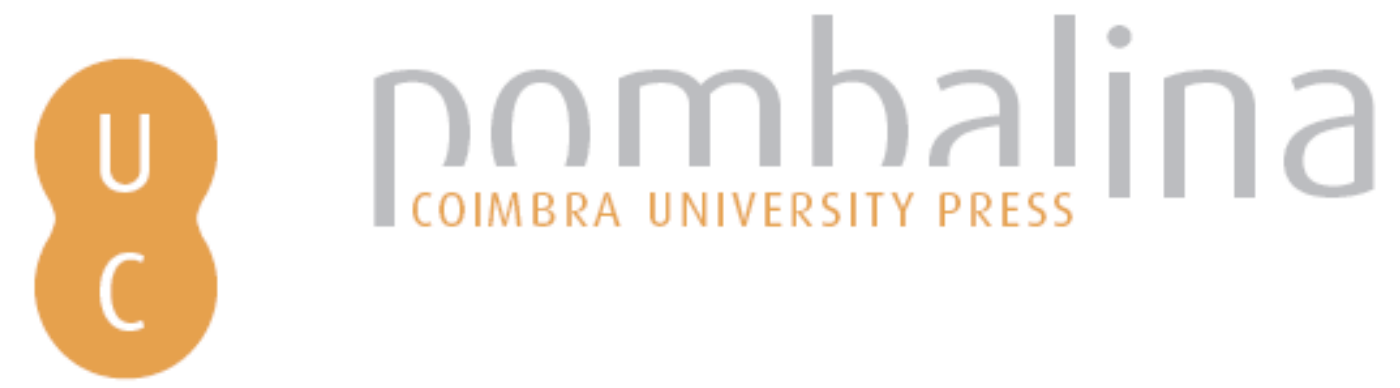

Colecionando heróis e inimigos: álbuns, panfletos e manuais de propaganda durante o Governo Vargas (19301945)
Autor(es):
Carneiro, Maria Luiza Tucci
Publicado por: Imprensa da Universidade de Coimbra
URL
persistente:
URI:http://hdl.handle.net/10316.2/38998
DOI:
DOI:http://dx.doi.org/10.14195/978-989-26-1064-1_4
Accessed : $\quad$ 26-Apr-2023 10:36:43

A navegação consulta e descarregamento dos títulos inseridos nas Bibliotecas Digitais UC Digitalis, UC Pombalina e UC Impactum, pressupõem a aceitação plena e sem reservas dos Termos e Condições de Uso destas Bibliotecas Digitais, disponíveis em https://digitalis.uc.pt/pt-pt/termos.

Conforme exposto nos referidos Termos e Condições de Uso, o descarregamento de títulos de acesso restrito requer uma licença válida de autorização devendo o utilizador aceder ao(s) documento(s) a partir de um endereço de IP da instituição detentora da supramencionada licença.

Ao utilizador é apenas permitido o descarregamento para uso pessoal, pelo que o emprego do(s) título(s) descarregado(s) para outro fim, designadamente comercial, carece de autorização do respetivo autor ou editor da obra.

Na medida em que todas as obras da UC Digitalis se encontram protegidas pelo Código do Direito de Autor e Direitos Conexos e demais legislação aplicável, toda a cópia, parcial ou total, deste documento, nos casos em que é legalmente admitida, deverá conter ou fazer-se acompanhar por este aviso.

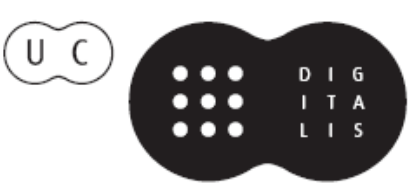


A L B ERTO PENA-RODR ÍGUEZ HELOISA PAULO

COOR D.

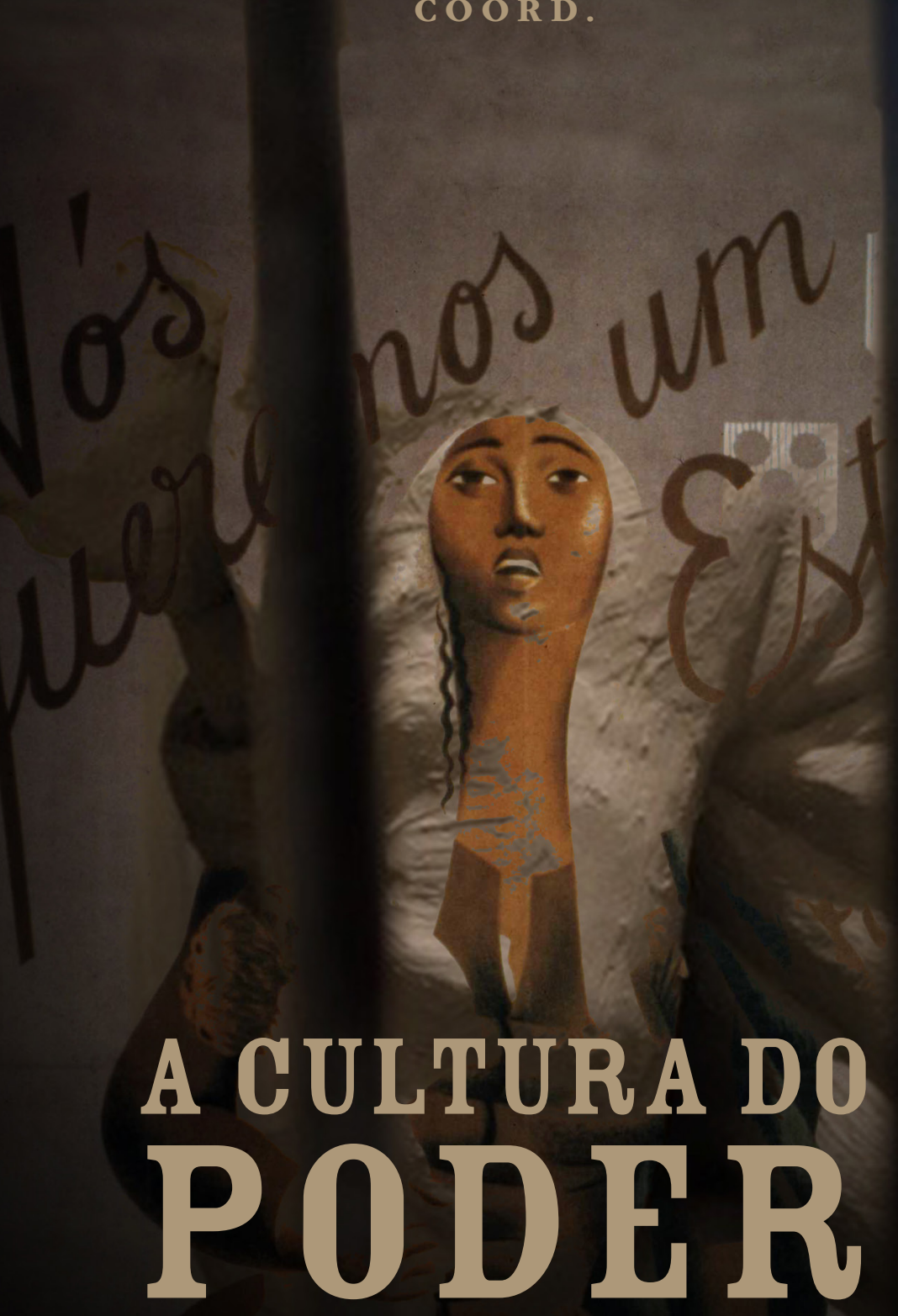

A PROPAGANDA INOS ESTADOS AUTORITÁRIOS 


\section{COLECIONANDO HERÓIS E INIMIGOS: Álbuns, panfletos e MANUAis de PROPAGANDA DURANTE O GOVERNO VARGAS (1930-1945) ${ }^{1}$}

Entre 1930 e 1945 circularam no Brasil, então governado por Getúlio Vargas (1882-1954), as mais diferentes formas de propaganda política que, liderada pelo poder instituído, tinha como objetivo promover heróis e incriminar os inimigos do regime. Álbuns de figurinhas e de fotografias exaltavam as lideranças brasileiras, assim como os feitos do Terceiro Reich, admirado por suas conquistas. A narrativa oficial - ao contrário daquela que persistiu durante a Primeira República (1889-1930) fundada na ideia de ausência - pautava-se pela presença de Vargas em todos os círculos das esferas públicas, destacado inicialmente como revolucionário de 1930, depois como "trabalhador n. 1 do Brasil", e finalmente, como presidente eleito pelo povo, apesar do golpe ditatorial de $1937 .{ }^{2}$

Exposições iconográficas, panfletos e cartões postais produzidos por órgãos governamentais e policiais, se prestavam para legitimar as ações de repressão aos "inimigos da pátria”, assim como para

1 A versão completa desta pesquisa será publicada no livro Panfletos Subversivos, da autoria desta mesma autora, pelo Ateliê Editorial (no prelo),

2 HOLlANDA, Cristina Buarque de. Modos de Representação Politica. O Experimento da Primeira República Brasileira. Belo Horizonte: Editora UFMG, Rio de Janeiro: IUPERJ, 2009. 
fortalecer a imagem de nação forte para um Brasil moderno. Ao endossar os paradigmas de comunicação adotados pelos regimes totalitários alemão e italiano, o governo brasileiro contribuiu para fomentar uma cultura que, durante décadas, serviu para sustentar mitos políticos. Apos o levante comunista de 1935, o governo procurou dar visibilidade aos atos de prisões aos comunistas, obcecados que estavam pela ideia de "perigo vermelho".

Fragmentos desta cultura política brasileira podem ser consultados nos arquivos do DIP- Departamento de Imprensa e Propaganda, fundado em 1938 e do DEOPS/SP- Departamento Estadual de Ordem Política e Social, a Polícia Política do Estado de São Paulo, criado em 1924. Enquanto censor, o DIP cuidava de calar as vozes destoantes dos diversos segmentos sociais que tentavam se posicionar contra o regime e os líderes da entourage de Vargas. Roubando a fala do povo, o DIP procurava manter a propaganda sistemática de legitimação do regime. Expressivos desta postura autoritária e populista são os estudos desenvolvidos pelos historiadores Silvana Goulart, Adalberto Paranhos e Maria Helena Capelato. ${ }^{3}$

A Polícia Política, enquanto aparato repressor, dedicou-se a vasculhar os porões da sociedade em busca dos inimigos do regime. Durante décadas, os comunistas foram eleitos "inimigos n..$^{\circ}$ " do Estado brasileiro, seguidos dos socialistas, anarquistas, judeus, maçons, negros, japoneses e ciganos, dentre outros grupos políticos e/ou étnicos avaliados como indesejáveis. Movido por lógica própria - a da desconfiança - e com a função específica de purificar a sociedade das ideologias e das "raças" ditas "malditas" ou "perni-

3 GOULART. Silvana. Sob a Verdade Oficial. Ideologia, Propaganda e Censura no Estado Novo. São Paulo: Marco Zero; CNPq, 1990; PARANHOS, Adalberto. O Roubo da Fala. Origens da Ideologia do Trabalhismo no Brasil. São Paulo: Boitempo, 1999; CAPElATO, Maria Helena. Multidões em Cena. Propaganda Politica no Varguismo e no Peronismo. Campinas: Papirus; Fapesp, 1998. 
ciosas" à ordem social, a Polícia Política aprimorou sua técnica de arquivar documentos confiscados diretamente dos seus produtores. Ao mesmo tempo, guardou em pastas próprias, inúmeros registros produzidos pela Secretaria de Segurança Pública idealizados com o propósito de orientar seus funcionários a identificarem e combaterem os subversivos da ordem, no caso, os comunistas.

Ações semelhantes foram também promovidas pelo órgãos de propaganda do Estado dedicados a interferir na mentalidade da população que, diariamente, era seduzida pela visão de futuro oferecida por um discurso salvacionista. Nas narrativas oficiais, Getúlio Vargas emerge como o herói que, sem derramar sangue, chegou para salvar o país do caos gerado pela "velha" República brasileira, cuja imagem se fazia construída com base em um passado forjado. A culpa era atribuída ao liberalismo que, incapaz de organizar a vida pública, havia instalado a instabilidade e a desordem social.

A propaganda oficial norteava o senso comum procurando conquistar certos segmentos sociais a colaborar com o processo de "higienização política" transformando-os em cidadãos coniventes com o Poder, a violência física e simbólica. Assim como na Alemanha nazista - guardadas as proporções entre os regimes totalitário e autoritário - o governo brasileiro procurou doutrinar os jovens através da educação e de organizações à exemplo da Juventude Brasileira, cujo projeto inicial foi apresentado em 1938 com o aval de Francisco Campos, então Ministro da Justiça. ${ }^{4}$ A proposta previa a criação da Organização Nacional da Juventude, instituição de âmbito nacional e caráter paramilitar, nos moldes das organizações fascistas existentes na Alemanha e Itália. O projeto foi reformulado mediante sugestões de Gustavo Capanema, Ministro da Educação durante o Estado Novo

${ }^{4}$ CUNHA, Célio da. Educação e Autoritarismo no Estado Novo. São Paulo: Cortez, 1981, p. 168. 
que, somente fez concessões para a sua instalação, no momento em que se cogitava o nome de Plínio Salgado para substituí-lo no Ministério. Criada efetivamente em março de 1940, a Juventude Brasileira deixou de ter um caráter de milícia para surgir como um movimento cívico, dedicada ao culto dos símbolos nacionais. Esvaziou-se com a entrada do Brasil na Segunda Guerra ao lado dos Aliados e, em agosto de 1945, foi extinta por um decreto-lei. ${ }^{5}$

A propaganda sustentada pelo Poder procurava induzir os mais jovens a hostilizar a República, os ideais democráticos e as liberdades individuais, apresentadas como "armas" dos inimigos interessados em desestruturar a sociedade. Situações semelhantes podem ser identificadas nos discursos oficiais que circularam durante os governos de Benito Mussolini (1895-1974), António de Oliveira Salazar (1889-1945), Francisco Franco (1892-1975) e Juan Domingues Perón (1883-1945). Resultados imediatos desta doutrinação, podem ser constatados através das fotografias que registraram cenas públicas de exaltação à Getúlio Vargas cuja imagem de ditador foi acobertada pela figura do "velhinho sorridente". Além de Vargas, as fotografias mostravam também uma juventude feliz, foco irradiante de beleza e alegria. Cumpre aqui citar a produção, em grande parte inédita, do fotógrafo alemão Peter Lange, favorito de Gustavo Capanema que, em 1942, encarregou-o de ilustrar a Obra Getuliana, livro-monumento idealizado para divulgar as realizações do governo Vargas durante o Estado Novo (1937-1945). Com fins pedagógicos de doutrinação e publicidade, esta obra foi, durante anos, "lapidada" por Capanema que, não chegou a publicá-la tendo em vista o final do governo Vargas em 1945.6

5 NUNES, José Luiz Martins. Juventude Brasileira: O Lado Fascista do Estado Novo. Caxias do Sul: Maneco, 2004.

${ }^{6}$ SCHWARTZMAN, Simon. Tempos de Capanema. 1. ${ }^{a}$ edição, São Paulo: Editora da Universidade de São Paulo; Editora Paz e Terra, $1984-2 .^{a}$ edição, Fundação Getúlio Vargas e Editora Paz e Terra, 2000. Ver também: LISSOVSKY,Mauricio; JAGUARIBE, 
Textos e imagens fixas e em movimento, procuravam forjar uma identidade nacional para o Brasil enquanto uma "comunidade política imaginada", valendo-me aqui do conceito de Benedict Anderson, ratificado por Stuart Hall. ${ }^{7}$ Ou seja, o material de propaganda produzido pelo governo durante o Estado Novo brasileiro (1937-1945), colaborou para fortalecer o vínculo identitário necessário para a construção da imagem de Nação moderna. Uma série de símbolos e formas de representações foram colocados em evidência com o objetivo de construir sentidos, dentre os quais os sentimentos de pertencimento e de brasilidade. A "construção" destes sentidos dependia, segundo versão oficial, da aplicação de um projeto nacional de educação que enfatizaria o catolicismo em detrimento de outras formas legítimas de religiosidade. Inclusive, a presença de Gustavo Capanema no Ministério da Educação e Cultura, teria atenuado a influência de ideologias autoritárias na área da educação. ${ }^{8}$

Beatriz, "A Invenção do Olhar Moderno na Era Vargas: Imagem Fotográfica e Imaginário social”, In: ECO-PÓS, v. 9, n.2, agosto-dezembro, 2006; LISSOVSKY, Mauricio; BLANK, Thaís. "Catástrofe do sentido e urgência da montagem: o Brasil em três fotogramas alemães dos anos 1930", In: Devires (UFMG), v. 7, p.151-165, 2010; LISSOVSKY, Mauricio; MELLO, Márcia, Refúgio do Olhar: a fotografia de Kurt Kalgsbrunn no Brasil dos anos 1940. Rio de Janeiro: Casa da Palavra, 2010; LISSOVSKY, Maurício, "Brasil, Refúgio do Olhar: Trajetória de um fotógrafo exilado no Rio de Janeiro dos anos 1940", pp. 90-91, in: http://www.unicentro.br/rbhm/ed04/dossie/03.pdf.

7 ANDERSON, Benedict. Comunidades Imaginadas. Trad. Denise Bottman. São Paulo: Companhia das Letras, 2008; HALL, Stuart. A Identidade Cultural na Pós-modernidade. Trad. Tomaz da Silva e Guaciane Lopes Lauro. 6 ed., Rio de Janeiro: DP e A, 2006.

8 CARNEIRO, Maria Luiza Tucci. O Anti-semitismo na Era Vargas: Fantasmas de uma Geração, 1930-1945, 3ed. São Paulo: Perspectiva, 2001. 


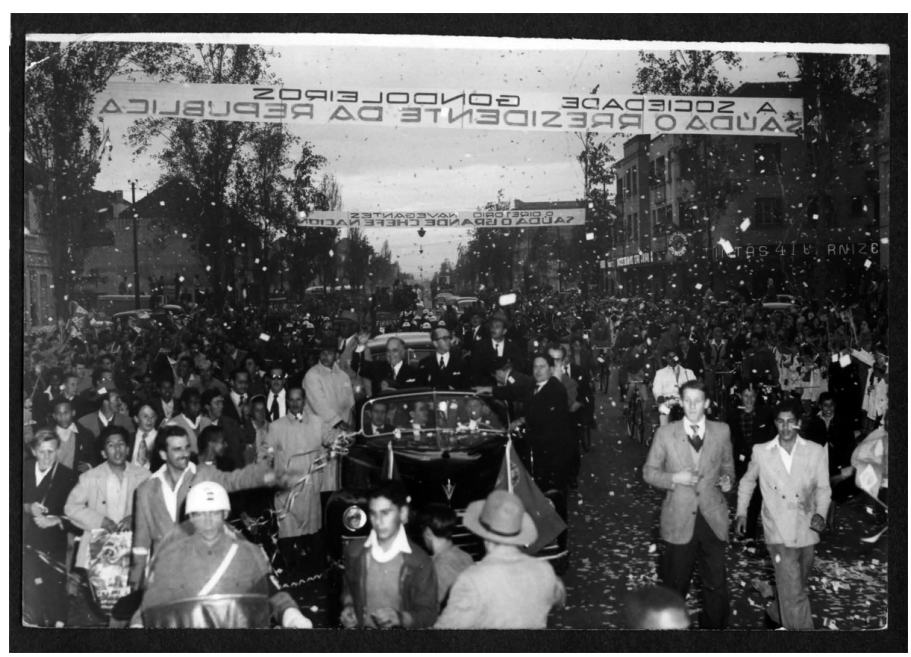

Fotógrafo não identificado. Getúlio Vargas é homenageado pelo povo gaúcho. Correio da Manhã, Rio de Janeiro, s. d. Arquivo Nacional do Rio de Janeiro.

BR_RJANRIO_PH_0_FOT_18089_410

\section{A construção da imagem do inimigo}

Graças a propaganda governamental, a perseguição sistemática e as prisões de centenas de comunistas entre 1935-1945, foram encaradas por parte da população como positiva. As narrativas e as imagens anticomunistas, contribuíam para inibir qualquer manifestação de dissenso, sendo interpretadas como necessárias para garantir a ordem e a felicidade do povo brasileiro. Assim, durante quinze anos consecutivos, as ações de repressão cultural e política, serviram para corroer deliberadamente o espírito democrático, cada vez mais fragilizado pelos atos autoritários de Vargas e seus correligionários.

O discurso do Estado ordenador assumiu, através da propaganda e da repressão policial, um tom acusatório (maniqueísta) ao apontar o inimigo cuja imagem foi sendo construída a partir de provas recolhidas junto aos espaços da sedição (daí os autos de busca e apreensão e os relatórios de investigação policiais). Nestes casos, quem redigia a 
versão "oficial" do crime de subversão era a autoridade policial que, com base na observação e na materialização do crime (provas impressas, por exemplo), construía realidades. E estas, ao serem julgadas pelas instâncias superiores e propagadas junto a grande imprensa, tornavam-se consenso, legitimando a imagem de Vargas como herói.

Cruzando a versão policial com as mensagens veiculadas junto a grande imprensa temos possibilidade de recuperar elementos que direcionavam o raciocínio "lógico" do Estado repressor. Em ambas as narrativas (do Estado e da grande imprensa), o subversivo de desponta como um ser desumano, imoral e violento, imagem que se faz reforçada pela fotografia que "torna visível" o perigo político. O jornal O Estado de S. Paulo, por exemplo, valia-se de imagens fotográficas - muitas das quais fornecidas pela própria Polícia Política - para reafirmar o conceito de malignidade do comunismo9. Daí a importância de levarmos em consideração os artigos de jornais que recortados pelos investigadores eram colados junto aos prontuários -- ainda que sem identificação de datas e páginas - contribuindo para redimensionar o crime praticado pelo indiciado, agora de domínio público. ${ }^{10} \mathrm{Grande}$ parte dos documentos impressos ou manuscritos confiscados do "suspeito de subversão" eram anexados aos prontuários e dossiês policiais ${ }^{11}$ com o objetivo de comprovar o delito de

\footnotetext{
${ }^{9}$ MOTTA, Rodrigo Patto Sá. Em guarda contra o "perigo Vermelho". O anticomunismo no Brasil (1917-1964). São Paulo: Perspectiva, 2001; NEGRÃO, João Henrique Botteri. Selvagens e Incendiários. A Imagem dos Comunistas no jornal O Estado de S. Paulo. São Paulo: Humanitas, 2005.

${ }^{10}$ Ver KOSSOY, Boris. Os Tempos da Fotografia. O Efémero e o Perpétuo. São Paulo: Ateliê Editorial, 2007; Realidades e Ficções na Trama Fotográfica. São Paulo: Ateliê Editorial, 1999.

${ }^{11}$ A Série Dossiês conta com cerca de $\mathbf{1 . 1 0 0 . 0 0 0 ~ f i c h a s ~ q u e ~ n o s ~ r e m e t e m ~ a ~ a p r o - ~}$ ximadamente 2 milhões de documentos distribuídos em 9.625 pastas. Este segmento do Fundo Deops de São Paulo foi inventariado pelo projeto "Mapeamento e Sistematização do Acervo Deops/SP", coordenado pela Prof ${ }^{a}$ Maria Aparecida de Aquino, do Departamento de História da USP. A Série Prontuários abrange mais de 150.000 prontuários e fichas remissivas, documentação que foi parcialmente digitalizada pelo Projeto Integrado Arquivo/Universidade, coordenado pelos professo-
} 
ideias. Identificado segundo o nome do cidadão ou da instituição investigada, cada processo pode ser interpretado como um "espaço recriado da memória" individual e coletiva, espaço este construído ao sabor dos preconceitos e no calor dos mitos políticos. Ao desempenhar sua função de aparato preventivo e repressivo, o Departamento de Ordem Política e Social ${ }^{12}$ transformou-se em um tipo especial de modalidade de polícia. Criado, segundo definição de Marília Xavier, com "fins de entrever e coibir reações políticas adversas, armadas ou não, que comprometessem a ordem e a segurança pública"13, este órgão se fez presente nos cantões escuros da sociedade. Os homens do Serviço Secreto (SS) - vigilantes incansáveis do Estado - infiltraram-se por todos os poros da sociedade em busca de provas materiais para comprovação do delito político. Desceram aos porões dos sobrados instalados nos bairros periféricos das cidades, vasculharam livrarias, tipografias e editoras que acobertavam células comunistas, reconhecidas como "antros da sedução e da sedição". Atentos a qualquer atitude suspeita, os homens do Serviço Secreto sentavam praça ou campaña em frente de uma ou outra residência em busca de indícios que lhes garantissem o ato de busca e apreensão.

A cada investida policial, abriam-se novos universos que, inventariados de acordo com critérios policiais, ofereciam uma multiplicidade de provas da prática subversiva. Tanto a seleção como o confisco das provas se faziam guiadas pela lógica da desconfiança. Se confiscadas, estas eram relacionadas e, muitas vezes, fotografadas pela equipe técnica do Laboratório de Fotografia do Gabinete de Investigação. Deslocados do seu "habitat", os documentos eram

res Boris Kossoy (Iconografia) e Maria Luiza Tucci Carneiro (Inventário), ambos da Universidade de São Paulo.

12 Optamos por empregar a sigla DOPS para nos referirmos a Polícia Política em nível federal; e DEOPS, em nível estadual.

13 XAVIER, Marília. "Antecedentes Institucionais da Polícia Política”, In: DOPS: A Lógica da Desconfiança. Rio de Janeiro: Secretaria de Estado da Justiça/Arquivo Público do Estado, 1996, p. 2. 
anexados aos autos de forma a compor com a narrativa do discurso policial ao serviço do autoritarismo explícito e implícito. É neste momento que os impressos, em seus diferentes suportes e múltiplas variáveis, ganham estatuto de prova documental. O olhar viciado do investigador sabia, de antemão, o que deveria procurar: jornais, panfletos, livros, partituras musicais, cartões postais, boletins, circulares, manifestos e filipetas, em qualquer idioma e grafia. Dos álbuns de família "arrancavam-se" fotografias que, inseridas nas folhas dos prontuários e dossiês, se prestavam para ilustrar a versão pretendida pela autoridade investida do poder de decisão. A partir do momento em que o Estado criou um órgão dedicado a reprimir idéias sediciosas, caçar a palavra impressa e penalizar seus mentores, anulava-se a noção de sociedade civil. Para as autoridades da repressão, o "produtor de um jornal" era apenas o outro, elemento provocador que, como tal, deveria ser isolado. Como conseqüência temos o retorno da razão do Estado que, em nome da segurança pública e bem-estar da nação, pode colocar fim no Estado de direito.
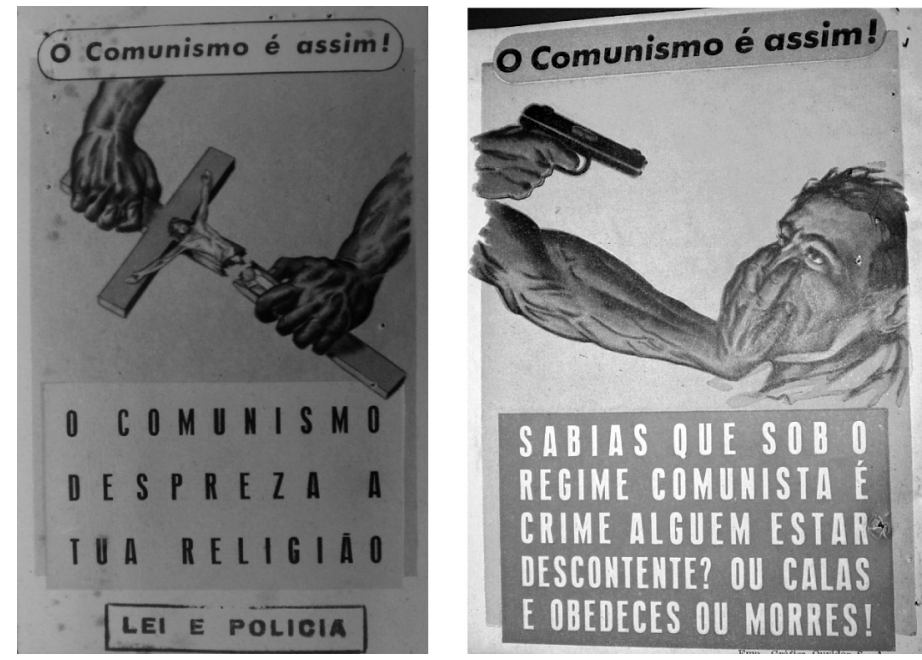

Livretos de propaganda anticomunista produzida pela Secretaria Pública de Segurança Nacional. Coleção "O comunismo é assim", como produção do programa Lei e Polícia. Fundo DEOPS/SP. APESP. 


\section{A linguagem sedutora dos impressos políticos}

Seguindo a trilha do impresso no Brasil chegaremos até os grupos políticos e movimentos sociais que, através de múltiplos subterfúgios, conseguiram formular suas propostas de ordem ou desordem, leia-se aqui de "revolução social". Empregando a metáfora da rede, desvendamos aqui uma trama de cidadãos mobilizados por autênticas estratégias de organização social ${ }^{14}$. A somatória dos impressos, além de definir certas identidades individuais e de grupo, expressa a formação de redes solidárias ao Estado, aos intelectuais, aos imigrantes e os nacionais, assim como aos cidadãos de todas as classes, raças e religiões. As mensagens multiplicadas são exemplos de representatividade dos vínculos comunitários, distintos por seus apelos e imagens utópicas.

Percebemos - ao analisar a linguagem adotada pelos grupos de resistência ao Estado republicano ou a ditadura varguista - que os seus produtores pretendiam dilatar sua esfera pessoal ou coletivo (espaço vital) conquistando objetos e status que pertenciam a esfera do Outro. Alguém era sempre culpado pela miséria e pelo atraso vivenciado pelo homem negro, pela mulher ou pelo trabalhador nacional que, asfixiados pelos patrões ou pelo Estado interventor, não conseguiam alcançar a felicidade plena ${ }^{15}$. Segundo o poder instituído, a felicidade deveria ser "conquistada" através do esforço coletivo, ideia alimentada por um sistema de motivações a ser elaborado (e colocado em prática) pelo Estado. No caso da contra-propaganda, esta ação era de responsabilidade dos líderes comu-

\footnotetext{
${ }^{14}$ Empregamos aqui o conceito de "rede" proposto por Franco Ramella para os estudos migratórios e que adaptamos, nesse caso, para os estudos das ideias políticas. Sobre o tema consultar: BJERG, Maria; OTERO, Hernán. Inmigración y Redes Sociales en la Argentina Moderna. Buenos Aires: CEMLA; IEHS, 1995.

15 Para os casos dos regimes totalitários e autoritários pode-se aplicar o conceito de inimígo-objetivo desenvolvido por ARENDT, Hannah. O Sistema Totalitário. Trad. Roberto Raposo. Lisboa: Publicações Dom Quixote, 1978.
} 
nitários ou dos partidos que tentavam sobreviver nos subterrâneos da sociedade ${ }^{16}$.

Consideramos que a propaganda política, em qualquer esfera de circulação, alimentava a imagem de um mundo fictício capaz de competir com o mundo real. O caos, a desordem, a miséria, a fome, a exclusão e a injustiça social seriam - segundo as mensagens sedutoras propagadas pelos grupos de oposição ao poder instituído - superadas por uma revolução social que prometia paz, felicidade, igualdade social etc. O mundo fictício - proposto pelos revolucionários de esquerda, por exemplo - distinguia-se daquele idealizado pelos nazistas ao criticar o uso da força, o abuso do poder e da violência.

\section{O papel dos panfletos}

Panfleto é feito de papel; panfleto e fácil de manusear, guardar, esconder ou eliminar. É de baixo custo e pode transmitir rapidamente uma mensagem para um grande público. Pode ser mimeografado ou impresso, com ou sem imagem, instigando o leitor a pensar, discutir e agir na vida prática, diária. Tem o poder de alterar a realidade ou reforçar o status quo colaborando para a mobilização ou a persistência da inércia, entenda-se aqui apatia ou conformismo. Folheto não tem capa (cobertura dura) e nem encadernação. Na sua maioria são confeccionados em uma única folha de papel cortada ou dobrada pela metade, em terços ou em quartos. Pelo seu formato "portátil", o folheto tornou-se um importante instrumento de propaganda política favorecendo a circulação da crítica e do protesto

16 Conceito é amplamente desenvolvido por Abraham Moles. Ver deste autor: O Cartaz. Trad. de Miriam Garcia Mendes. São Paulo: Editora Perspectiva; Edusp, 1974 (Coleção Debates, 74). 
proibido. Diferente do livro, o panfleto não para em pé: deve ser lido rapidamente e, se guardado, deve ser "enrolado", "dobrado" ou "mantido na horizontal". Por esta característica particular favorece as ações políticas oficiais ou clandestinas.

Folheto de uma única página, o panfleto é chamado "voador" ou "relâmpago": anuncia, convoca e promete felicidade em troca da adesão. Um panfleto político voador é, quase sempre, portador de uma mensagem relâmpago que, por sua natureza instintiva, deve causar impacto e mobilizar as massas. Confeccionado em uma única folha de papel, tem o poder de convocação, de chamada, de denúncia ou de alerta. Ao mesmo tempo é coletivo e introspectivo favorecendo a inserção social de certas individualidades, pois os textos e as imagens traduzem particularidades das visões de mundo do autor do panfleto, além de refletir perspectivas coletivas e político-partidárias. Enquanto impressos volantes têm vida cíclica pressupondo distintas fases que vão da sua criação à morte para depois renascer graças à revitalização das ideias. Retomo aqui a epígrafe do livro de Domingos Braz: Morrem os Homens...mas a idéia fica! ${ }^{17}$

Multiplicado aos milhares, passa de mão em mão, sendo distribuído nas praças, nas ruas ou em ambientes fechados. Colados nos postes, nos muros, nas portas ou nas paredes chamam a atenção do público-alvo que, movido por algum interesse, pára para ler ou arrancá-lo, num ato de repúdio ou conivência. Uns carecem de criatividade; outros brilham por serem irreverentes e por estarem "fora da ordem". Enquanto instrumento de propaganda política são seculares e universais; e enquanto registro ideológico são temporais, expressão de um momento específico da história do país.

17 BRAZ, Domingos. Dos Meus Momentos de Lazer: Morrem os Homens... Mas a Idéia Fica!, s.d. Anexado ao Pront. $n^{\circ}$ 493, de Domingos Braz, Vol. 2. DEOPS/SP. APESP. Sobre livros confiscados ver CARNEIRO, Maria Luiza Tucci. Livros Proibidos, Idéias Malditas, 2. ${ }^{a}$ ed., São Paulo: Ateliê Editorial, 2002. 
O panfleto - assim como o jornal, o livro e as filipetas - sempre se apresentou como alternativa eficaz de propaganda política. Adotado no Brasil desde o início do século XIX, o panfleto deve ser avaliado como um dos mais importantes registros da memória política do país. Alguns deles inscrevem-se numa tradição dos impressos liberais e revolucionários; outros emergiram como tipicamente anti-monarquista, anti-lusitanos, nacionalistas ao extremo e, até mesmo, anticlericais. Estudos desenvolvidos por Lúcia Maria Bastos Neves têm demonstrado que os panfletos começaram a circular no Brasil a em decorrência da Revolução do Porto de 1820 e do movimento de 26 de fevereiro de 1921, promotores de ideias liberais e constitucionais. Publicados em Lisboa, Bahia, Rio de Janeiro, Pará, Maranhão e Pernambuco, esses impressos levaram o debate político para as ruas favorecendo a construção de uma cultura política. ${ }^{18}$

A partir das últimas décadas do século XIX começaram a ser produzidos panfletos expressivos do movimento republicano, negro, anarquista, operário, sindicalista, comunista e antifascista. Aqueles produzidos pelos grupos "exóticos" - ou seja, da esquerda revolucionária - sempre encontraram barreiras para circular rompendo com o mundo da clandestinidade; o que não era tão comum com relação aos impressos expressivos da ação da extrema-direita que raramente teve suas publicações censuradas pelas autoridades do Poder. Quando isto aconteceu, a repressão não se fez tão radical ${ }^{19}$.

Os impressos revolucionários que circularam no Brasil desde o final do século XIX - e principalmente aqueles que circularam na clandestinidade por força da censura institucional - ainda estão por serem conhecidos. Sua trajetória, cujos meandros nem sempre são

18 NEVES, Lúcia Maria Bastos P., "Cidadania e participação política na época da Independência do Brasil”, In: Caderno CEDES, v.22, n 58, Campinas, dez., 2002.

19 Como exemplo temos os casos dos jornais Offensiva, criado e dirigido por Plínio Salgado (maio de 1934 a março de 1938) e O Integralista, Órgão da Acção Integralista em São Paulo. Cf. Pront. $n .^{\circ} 1583$, Acção Integralista. DEOPS/SP. AESP. 
fáceis de descobrir, pode ser comparada ao traçado de um labirinto cujas entradas e saídas se encontram ora interrompidas, ora abertas para o mundo múltiplo da resistência. Esses impressos, e em especial os panfletos, desempenharam importante papel na organização do operariado brasileiro conscientizando-o das suas possibilidades de ação enquanto agente social e como classe. Eles são, assim como os jornais e os livros, "investidos de significações plurais e móveis, que se constroem no encontro de uma proposição com uma recepção". ${ }^{20}$ Instigaram a rebeldia minando a apatia almejada pelas elites dominantes.

Valendo-se de um pequeno texto construído em tom convocatório, os panfletos raramente usam a imagem. Favorecendo a leitura dinâmica, convocam o individuo à rebelião procurando quebrar a apatia, cristalizada pelo discurso oficial. Com frases curtas compostas com palavras emprestadas do linguajar popular, denunciavam as injustiças da justiça brasileira dedicada, em vários momentos, a calar a voz dos rebeldes. Abriram espaço para a ação dos grupos de resistência ao autoritarismo rompendo com os preconceitos de cor, gênero, classe e religião. Mobilizaram -- numa frente única em prol dos direitos humanos -- estudantes, operários, intelectuais, artistas plásticos, músicos, caricaturistas e editores, homens e mulheres. Denunciaram a podridão das prisões brasileiras, a inadimplência das autoridades policiais, a desobediência as leis trabalhistas, a expulsão de estrangeiros e a censura oficial.

Identificando os caminhos trilhados por estes panfletos - do porto para a cidade, da capital para o interior ou da cidade para o campo - estaremos pontuando os espaços e as comunidades de leitores distintas por sua identidade étnica, nacional ou ideológica.

${ }^{20}$ CHARTIER, Roger. A Ordem dos Livros. Leitores, Autores e Bibliotecas na Europa entre os Séculos XIV e XVIII. Trad. Mary Del Priori. Brasília: Editora UnB, 1999, pp. 8-9. 
Enquanto impressos convocatórios, os panfletos invadiram [clandestinamente] as residências onde foram lidos por todas as classes, sem exceção: leitores curiosos, leitores pervertidos, leitores malditos. Aliás, é raro quem não tenha experimentado, um dia, o sabor de uma leitura proibida! Seguindo os trilhos de ferro, a "panfletagem subversiva" foi levada, às escondidas, até as cidadezinhas do interior incomodando o sossego das elites regionais, adeptas do coronelismo. Incomodaram, certamente, empresários, políticos, coronéis e fazendeiros acostumados ao mando, por tradição.

Editados em português, na sua maioria, os panfletos expressam as plataformas políticas dos mais distintos grupos sociais. Serviam como provas comprometedoras do crime político, de acordo com a lógica da desconfiança adotada pelas autoridades policiais cientes do poder das palavras de ordem. Um slogan ou uma imagem eram suficientes para transformar aquelas páginas de papel em manuais de revolução. Sobre os produtores - interpretados como mentores intelectuais do crime político - recaia a culpa pela infração: eles haviam ultrapassado os limites do permitido. Se reincidentes transformavam-se em "reféns do seu próprio passado", distinção formal decorrente do estigma da criminalização, do labelling approach ou teoria do etiquetamento. ${ }^{21}$

A apreensão dos panfletos ditos perigosos e a sistemática prisão de seus produtores, impressores e distribuidores deve ser avaliada como a formulação de uma resposta institucional à ameaça representada por aqueles que atentavam contra a estabilidade das elites políticas. Daí considerarmos esta "literatura" como efêmera, dada a sua curta trajetória enquanto meio genuíno de comunicação de massas. A partir do momento em que o Estado criou um órgão de-

${ }^{21}$ Sobre esta questão ver BRISSOLI FILHO, Francisco. Estigmas da Criminalização: dos antecedentes à reincidência criminal. Florianópolis: Editora Obra Jurídica, 1998. 
dicado a reprimir idéias sediciosas, caçar a palavra e penalizar seus mentores, anulava-se a noção de sociedade civil. Os descontentes não eram reconhecidos pelo discurso oficial, de tal forma que durante os conflitos sociais eram considerados ilegítimos e, como tais, presos e julgados por seus desvios. Para as autoridades dominantes, um "produtor de panfleto" era apenas o "outro", elemento provocador que, como tal, deveria ser isolado ${ }^{22}$.

Uma nova linguagem tomou dos discursos políticos nas décadas de 1030-1940 - do ordenador e do revolucionário -- sendo que este último levava a pecha de "desordenador da ordem pública". Os panfletos, geralmente desafiavam os estatutos da ordem funcionando como uma espécie de prolongamento da ação subversiva. E como sempre, desordem requer controle; controle atrai a censura que, por sua vez, culmina com a repressão física e simbólica. O círculo é vicioso e, como todo vício, atrofia o exercício da cidadania.

\section{Uma questão de estilo}

Levando em consideração o produtor, a mensagem, a iconografia e o público-alvo, os panfletos políticos podem ser agrupados em "categorias literárias", seguindo critérios sugeridos por Antoine de Baecque: reflexões sobre o governo e as instituições, o ensaio político; o cotidiano político e a polêmica. Considerando-se as circunstâncias em que tais impressos foram produzidos no Brasil (1924-1954)23

\footnotetext{
22 MATOS, Olgária Chain Feres, "Espaço público e tolerância política”, In: MIRANDA, Wander Melo. Narrativas da Modernidade (Org.). Belo Horizonte: Autêntica, 1999, p. 343.

23 Apenas a título de informação: estas datas foram adotadas com um objetivo didático, tendo em vista a dimensão documental do Fundo DEOPS/SP. Estes marcos são adotados por todos os projetos de pesquisa desenvolvidos junto ao PROIN Arquivo/ Universidade sob a orientação desta Autora [1924: criação do DEOPS/SP; e 1954: fim do segundo governo de Getúlio Vargas].
} 
podemos defini-los como pobres em imagens visuais e fortes em imagens mentais. Diferenciando-se o cartaz e do poster - geralmente ilustrados com reproduções fotográficas de alta resolução - o panfleto político não traz, necessariamente, uma dimensão estética. Tem como prioridade, levar a mensagem de uma coletividade ao indivíduo procurando estimular a produção de novos comportamentos. Daí propormos que a análise da mensagem siga sempre em duas direções, conforme sugestão de Abraham Moles para o estudo do cartaz: a mensagem semântica ou denotativa; e a mensagem estética ou conotativa. ${ }^{24}$ As mensagens propagadas pelos panfletos devem ser avaliadas como ingredientes de um processo em curso e, não apenas, como registro do passado. Basicamente, esses impressos cumprem o papel didático de informar, seduzir, educar e evocar imagens memorizadas. É quando a linguagem semântica sobrepõe-se [ou superpõe-se] a estética oferecendo conteúdo para a elaboração de um vocabulário de conceitos e mitos políticos. ${ }^{25}$

De uma forma geral, as narrativas permitem reconstituir as imagens mentais de Nação e Povo, de inimigo-objetivo e, simultaneamente, o auto-retrato "construído" pelo grupo produtor. A imagem do inimigo-objetivo se faz, na maioria das vezes, a partir de um processo de desumanização/animalização do sujeito. Para as comunidades políticas identificadas com o ideário das esquerdas, por exemplo, o inimigo/alvo era Vargas, Hitler, Franco, as elites agrárias, a burguesia industrial, dentre outros personagens identificados como "exploradores do povo", "destruidores da democracia", "assassinos dos operários", "ditadores", "exploradores" etc. Dentre as instituições constantemente criticadas estavam o Estado republicano, a Igreja Católica e a Polícia Política, identificados enquanto agentes da repressão, da corrupção e da intolerância.

\footnotetext{
${ }^{24}$ Abraham Moles, op. cit., p. 27.

25 Idem, pp. 4757 e 63-78.
} 
$\mathrm{Na}$ contramão do discurso antivarguista e antifascista, o discurso oficial -- valendo-se de políticas públicas de poder -- investiu contra os negros, os judeus, negros, os japoneses, os ciganos, os comunistas, os anarquistas e socialistas. Qualquer indivíduo, independente da sua classe social, gênero, profissão, nível cultural ou idade poderia ser um suspeito em potencial: homens ou mulheres, jovens ou velhos, intelectuais ou analfabetos, operários ou lavradores, negro ou branco, para enumerar alguns.

Tanto o discurso antifascista como o discurso oficial em circulação no período de 1930-1954, têm elementos comuns, conforme constatado pelos pesquisadores do PROIN- Projeto Integrado Arquivo do Estado/Universidade de São Paulo ${ }^{26}$ :

- Valiam-se da panfletagem para colocar em circulação uma retórica maniqueísta investida de dois elementos de primeira grandeza: a difamação e a exaltação;

- Através desta retórica argumentativa interferiam na construção de uma "verdade" histórica;

- Na ideologia dos autores/produtores do panfleto, o seu líder político era o Salvador de todos os males que afligiam a Nação e o povo brasileiros, alimentando mitos políticos.

A pretensão era sempre educativa ou convocatória do público-alvo que, nem sempre se mostrava sensível às reivindicações pois estavam anestesiados pelas forças do poder. Sem pretender reduzir nossa análise à velha dualidade e polaridade do Bem contra o Mal,

${ }^{26}$ Cumpre aqui citar duas importantes pesquisas desenvolvidas com bolsa de Iniciação Científica Fapesp junto ao PROIN, entre 2000 e 2004: SANTANA, Márcio M. Avante, Jovens Rebeldes! A Juventude Brasileira e o Aparato Repressivo do Governo Vargas (1935-45); SANTOS, Edney dos. Homens Trabalhando, Polícia Vigiando, sob a minha orientação. 
podemos agrupar o discurso panfletário em dois grupos distintos em seus objetivos:

1) De resistência ao autoritarismo, com ênfase na produção dos grupos identificados com as esquerdas que investiam na formação de uma consciência política da massa trabalhadora;

2) Dos governistas que procuravam anestesiar o espírito crítico e investir na domesticação da classe trabalhadora. Os grupos identificados como "revolucionários" ou "subversivos" tinham as suas ações limitadas pela censura institucionalizada pelo Estado republicano e pelas barreiras físicas impostas pela clandestinidade em que eram obrigados a viver. Interpretados pelas elites políticas republicanas como "defensores de um projeto de destruição da ordem capitalista”, foram caçados como homens fora-da-lei, portadores de "outras vontades", indesejáveis. Enfim, o mapeamento e análises sistemáticas dos panfletos permitem a identificação destas fraturas ideológicas expressivas das tensões e das negociações sociais. Enquanto promotores de uma cultura política, os panfletos podem ser classificados de acordo com o seu estilo, técnica e formato. ${ }^{27}$

\footnotetext{
${ }^{27}$ Lúcia Neves analisando os panfletos produzidos nos anos de 1820, exemplifica alguns dos estilos possíveis: a) os constitucionais: que procuravam explicar o vocabulário político liberal. Exemplo: a Constituição Explicada, que examinava o pensamento de Benjamin Constant; o Constitucional Justificado; b) de perguntas e respostas: o Catecismo Constitucional; c) de diálogo: como o Diálogo entre o Corcunda Abatido e o Constitucional Exaltado, uma conversa entre um alfaiate e seus fregueses, seguindo o modelo clássico do famoso Spectator de Addison e Steele, (Inglaterra, princípios do século XVIII"; d) de cartas escritas a amigos e compadres: a exemplo daquela escrita pelo compadre de Belém ao redator do jornal português Astro da Lusitânia; e) de farsas em verso e a dicionários: como o Dicionário Corcundativo ou Explicações das Phrazes dos Corcundas (Rio de Janeiro, 1921), parodiando orações religiosas: como o folheto A regeneração constitucional ou a guerra e a disputas entre os Carcundas [sic] e Constitucionais (1821). NEVES, Lúcia Maria Bastos, "Cidadania e participação política...", op. cit., p. 9.
} 
No caso dos panfletos políticos confiscados pela Polícia Política do Estado de São Paulo entre 1924-1954, conseguimos identificar alguns estilos:

- De alerta, com caráter preventivo: como o panfleto "Alerta, Povo de Taquaritinga!"; "Alerta, 2 de setembro"; "Brasileiros de todos os quartéis". ${ }^{28}$

- De denúncia e repúdio [ao governo, as instituições e aos patrões]: como o " 23 de maio e 9 de julho de 1932 . Ao Povo Paulista"; "Aos trabalhadores e ao povo em geral. Arbitrariedades e violências policiaes"; "Contra as provocações de Getulio, Ráo, Muller e seus comparsas!"; "Contra o assassinato dos inocentes acusados pelo incêndio do Reichstag!"; "Contra o 'vale’ e o `barracão`; "Os plutocratas

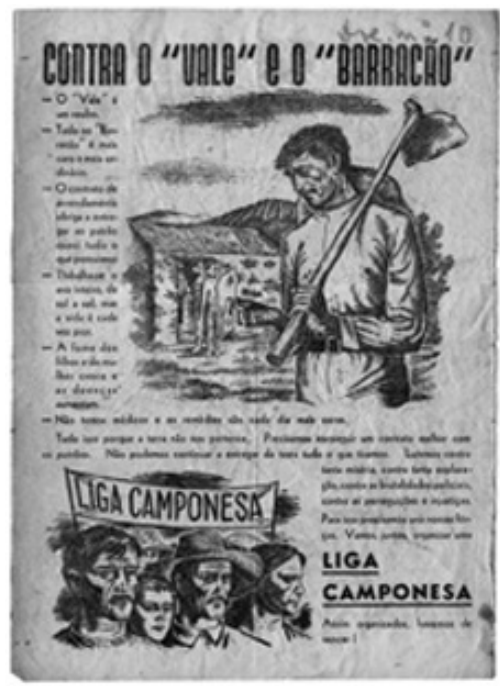

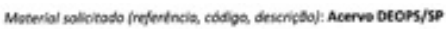

Prostudrio ns, 1038 Uvretos de propaganda anticomunibs probusida pela Secretaria Publka de Sepuranca Nacional Colesła "O cemunivmo t asuim", como produça do programa Lei e policis.

Pantleto Teuta da Mae Freta". Sas Pavib, 31 de dezembro de 1909.

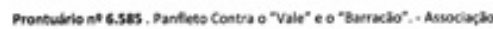
Arepecubra de SSo lost do Rio Parda, 30 de cutubro de 1945 .

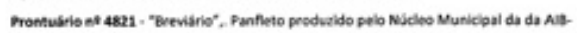
Acclo inbegilita Basileira de Jundahy, com texto de Guitavo Bartono.

Prontubrio no sss - vol. il - Panfleto Pat entre Nas, Guerra aos Senhores, Terra e Uterdade. Delecacis de Polleia de Crueeiro.

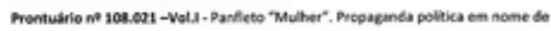
Elsa Kaulmans.

Panfleto "Contra o "Vale" o o "Barracão", Associação Agropecuária de São José do Rio Pardo, 30/10/1946. Confiscado e anexado ao Pront. 6585. Fundo DEOPS/SP. APESP.

28 "Alerta, Povo de Taquaritinga". Pront. n. ${ }^{\circ} 7554$; "Alerta, 2 de setembro". Pront. $n .^{\circ}$ 101.018; "Brasileiros de todos os quartéis", Pront. $n .^{\circ} 4663$, DEOPS/SP/AESP. 
nacionais e estrangeiros tramam uma nova chacina do povo trabalhador". ${ }^{29}$

- De chamamento para a ação: com mensagens curtas, telegráficas, instigando o leitor a tomar uma atitude revolucionária: "Desperta Brasil! Por um Governo Nacional Revolucionário”; "Libertemos Genny Gleyzer"; "Operários! Guerra aos acidentes do trabalho"; "À população da Alta Mogyana- Luis Carlos Prestes chama". ${ }^{30}$

- Convidativos: convidando para um churrasco, piquenique, teatro, a exemplo do panfleto "Grandioso Festival Artístico", produzido pelo Grêmio Dramático hispânico-Americano em favor da República espanhola. 31

- Educativos: estilo "volante" convidando para convenções, palestras e conferências proferidas por "ilustres intelectuais, artistas e jornalistas", como "Conferencias Publicas. Ao Povo"; "Congressos Eucarísticos"; "Convenção pela Emancipação Nacional". 32 O "Convite às Mulheres de São Paulo e ao Povo

29 "23 de maio e 9 de julho de 1932. Ao Povo Paulista", Pront. $n .{ }^{\circ}$ 1467; "Aos trabalhadores e ao povo em geral. Arbitrariedades e violências policiaes", Pront. $n .^{\circ} 1020$; "Contra as provocações de Getúlio, Ráo, Muller e seus comparsas!". Panfleto produzido pelo Diretório Nacional da A.N.L., Pront. 4262; "Contra o assassinato dos inocentes acusados pelo incendio do Reichstag !". panfleto produzido pelo P.C.B., Pront. $n .^{\circ} 1110$, v. 1; "Contra o 'vale` e o 'barracão`. São Paulo: Liga Camponesa, s. d.; Pront. $n .{ }^{\circ} 6585$; "Os plutocratas nacionais e estrangeiros tramam uma nova chacina do povo trabalhador". Panfleto do Comitê Regional do P.C.B., São Paulo, 28 de junho de 1935, Pront. $n .^{\circ}$ 209, v.1. DEOPS/SP. APESP.

30 "Desperta Brasil !. Por um Governo Nacional Revolucionário com Luiz Carlos Prestes à frente!", São Paulo, s.d. Pront. n. ${ }^{\circ} 1110$, v. 7; "Libertemos Genney", Pront. n. ${ }^{\circ} 40473$; "Operários! Guerra aos Acidentes do Trabalho", Pront. n. ${ }^{\circ}$ 5031; À população da Alta Mogyana- Luis Carlos Prestes chama". Panfleto da Alliança Nacional Libertadora do Brasil, transcrito do Diário da Noite, São Paulo, 28 de fevereiro de 1935. Pront. $n .^{\circ} 3355$ DEOPS/SP. APESP.

31 "Grandioso Festival Artístico", Panfleto produzido pelo Grêmio Dramático hispânico-Americano em favor da República espanhola. Pront. $n .^{\circ} 2.152$. DEOPS/ SP. APESP.

32 "Conferências Publicas". Panfleto produzido pela Aliança Nacional Libertadora, São Paulo, julho de 1935, Pront. $n .^{\circ}$ 209; "Congressos Eucarísticos", Panfleto produzido por Carlos Teixeira, Pront. $n .^{\circ} 3742$; "Convenção pela Emancipação Nacional. 
em Geral", por exemplo, anunciava como "fato único na vida feminina de São Paulo", a conferência da Mme. Marie Claude Vaillante Coutourier, secretária geral da Federação Mundial de Mulheres, deputada e heroína da resistência francesa. 33 Com a data de 18 março de 1933, a FOSP- Federação Operária de São Paulo distribuiu o panfleto "Conferência Educativa" convidando os trabalhadores para assistirem à conferência do Professor José Oiticica que iria "dissertar sobre um thema de actualidade social”. 34

- De breviário: em tom de cartilha política, enumera sob a forma de pequenos verbetes os erros e as mazelas cometidas pelos "inimigos" ou define conceitos políticos, como "individualismo", "liberalismo", "integralismo" etc. Exemplo: o panfleto "Breviário", produzido pela Acção Integralista Brasileira [Núcleo Municipal de Jundiahy ${ }^{35}$.

- De poéticas da subversão: composto com versos doutrinários, como o panfleto "Companheira. Profissão de Fé Proletária”, assinado por Cid Franco; "A Escandalosa”. 36

- Cartas: assinadas por reconhecidos líderes políticos, como o panfleto "Carta de Luiz Carlos Prestes dirigida a Alliança Nacional Libertadora". ${ }^{37}$

Convite ao Povo", assinado por Ary Normanton. Jundiaí, fevereiro de 1954, Pront. $n .^{\circ} 581$; DEOPS/SP. APESP.

33 "Convite às mulheres de São Paulo e ao povo em geral". Panfleto da União das Mulheres Democráticas de São Paulo, São Paulo, s. d. Pront. $n .^{\circ} 72712$. DEOPS/ SP. APESP.

34 "Conferência Educativa". São Paulo, 18 de março de 1933. Pront. n. ${ }^{\circ} 716$, Federação Operária de São Paulo, v.3. DEOPS/SP. APESP.

35 "Breviário",. Panfleto produzido pelo Núcleo Municipal da da AIB-Acção Integralista Brasileira de Jundiahy, com texto de Gustavo Barroso, Pront. $n .^{\circ} 4821$, DEOPS/SP. APESP.

36 "Companheira. Profissão de Fé Proletária", de Cide Franco; "A Escandalosa", Transcrito da A Manhã, 4 setembro de 1947, Pront. $n .^{\circ} 856$, DEOPS/SP. APESP.

37 "Carta de Luiz Carlos Prestes dirigida Alliança Nacional Libertadora", Barcelona, 23 de abril de 1935. Panfleto anexo ao Pront. $n .^{\circ} 4295$, v.1, DEOPS/SP. APESP 
- De rememoração de fatos históricos: em tom de ato público por ocasião da passagem de uma data histórica com "funestas conseqüências para a humanidade", como o panfleto "Centro de Cultura Social. Ato Público". Este impresso tinha como objetivo ilustrar aos trabalhadores sobre o significado do dia 11 de fevereiro, aniversário da assinatura do Tratado de Latrão em 1929. A explicação para este "vergonhoso tratado" era a de que Benito Musolini - identificado como "o tirano que oprimia a Itália" - havia cedido ao papa "a jurisdição e domínio da cidade do Vaticano...". 38 Outras datas serviam como referência para protestos políticos dos grupos de esquerda: a morte de Sacco e Vanzetti, o fuzilamento do poeta espanhol Garcia Lorca, e o fuzilamento do catalão Francisco Ferrer, além do tradicional Primeiro de Maio (Dia do Trabalho) e Dezoito de Maio (Abolição da Escravatura).

- De pergunta e resposta: no formato de um questionário político que, além de informar, apresenta solução imediata para o problema; "É admissível Prestes encarcerado?"; "Como lutar?" "Como deves tomar a terra?".39

38 Panfleto "Centro de Cultura Social. Ato Público", assinado pela Comissão Executiva. São Paulo, s.d., Pront. $n .^{\circ} 1914$, DEOPS, APESP. O Tratado de Latrão citado neste impresso foi assinado pelo Cardeal Gasparri, que era, em 1929, o Cardeal Secretário de Estado da Santa Sé. Por esse tratado, o governo italiano reconhecia o Vaticano como Estado soberano. Por seu lado, a Santa Sé cedia à Itália todas as terras dos antigos Estados Pontifícios, que o Papa havia governado desde o século $\mathrm{V}$ até 1870 , quando o Piemonte tomou à força os territórios pontifícios. Desde 1870 até 1929, os Papas se consideraram "prisioneiros no Vaticano, rompendo relações com o Estado italiano que conquistara Roma à força.

39 "É admissível Prestes encarcerado?". Panfleto do Diretório Estadual da A.N.L. apreendido em 25 de julho de 1936, São Paulo, s.d, Pront. $n .^{\circ}$ 1467; "Como lutar? Como deves tomar a terra?", Pront. $n .^{\circ} 555$; DEOPS/SP. APESP. 


\section{Panfletagem salvacionista}

A ideia de consenso social foi constantemente empregada pelo Estado nacional brasileiro que desde o início da era republicana, investiu contra as discordâncias, agindo com violência e arbítrio. Com o fechamento do Congresso em 3 de novembro de 1891 e a suspensão da liberdade de imprensa, fortalecia a ideia de consenso nacional que, ao longo de décadas, assumiria a força de mito. Sem conseguir se desvencilhar das mazelas do passado colonial, a República apresentou-se em nome da modernidade e dos ideais civilizatórios. Cabe lembrar que as elites políticas se reestruturaram sem se desprender das suas tradicionais bases agrárias, fontes para seus recursos políticos e sociais. Assumiram o papel de "elites modernas" aproveitando-se da não-interferência das massas urbanas que, neste primeiro momento, estavam afastadas das propostas revolucionárias do liberalismo.

Ao longo do século XX é possível perceber como o Estado foi forjando um sentimento de identidade nacional brasileira ao apelar para a imagem de um Brasil multi-racial, aberto a todas as etnias "independente da religião, raça e nacionalidade". Os impressos oficiais - pensando aqui nos álbuns comemorativos, nas revistas ilustradas, nos jornais da grande imprensa, nos panfletos políticos e nas obras de renomados intelectuais dedicados a pensar soluções para os "males da nação"- cumpriram um importante papel ao reafirmarem o sistema de dominação amordaçando aqueles que "eram do contra". Adotaram procedimentos de exclusão, sendo a interdição o mais evidente e comum. Apesar das leis de censura e de expulsão, os discursos "subversivos conseguiram circular na clandestinidade, registrando a "aparição de novas formas na vontade de verdade", retomando aqui Michel Foucault em A Ordem do Discurso. ${ }^{40}$

40 FOUCAULT, Michel. A Ordem do Discurso, Aula Inaugural no Collège de France, pronunciada em 2 de Dezembro de 1970, Trad. Laura Fraga de Almeida Sampaio. São 
Portanto, o consenso não era assim tão uniforme ainda que este tenha sido o tom do discurso oficial ao longo de décadas. A análise destes registros permite, se avaliados em um tempo de longa duração, uma reflexão sobre as rupturas e as permanências. Nas décadas de 1930-1940 não podemos negligenciar a figura de Vargas que, além de articulador político hábil em "construir" consensos e harmonizar interesses, era também um líder autoritário, assim como o definiu Eli Diniz:

“...maquiavélico, especialista na arte de dissimular, de esconder suas reais intenções e manipular as situações a seu favor, enfim, um mestre no emprego da astúcia e da força ao sabor de suas conveniências políticas". ${ }^{41}$

Tornou-se comum nos panfletos oficiais o apelo ao simbolismo católico com o objetivo de cooptar as massas para a nova ordem instituída pelo golpe de 1930. Analisando uma amostragem dos impressos produzidos pelos partidos da situação, colaboracionistas do Estado varguista, é possível constatarmos apropriações do discurso católico e de ícones populares presentes no imaginário coletivo. Proliferava-se o apelo à figura da Virgem Maria-mãe, assim como ao bandeirante desbravador das selvas brasileiras e do pai de família, incansável trabalhador.

Paulo: Edições Loyola, 1996, pp.17-18.

${ }^{41}$ DINIZ, Eli, "Engenharia institucional e políticas públicas: dos conselhos técnicos às câmaras setoriais", In: Dulce Pandorfi (Org.), op. cit., p.21. 


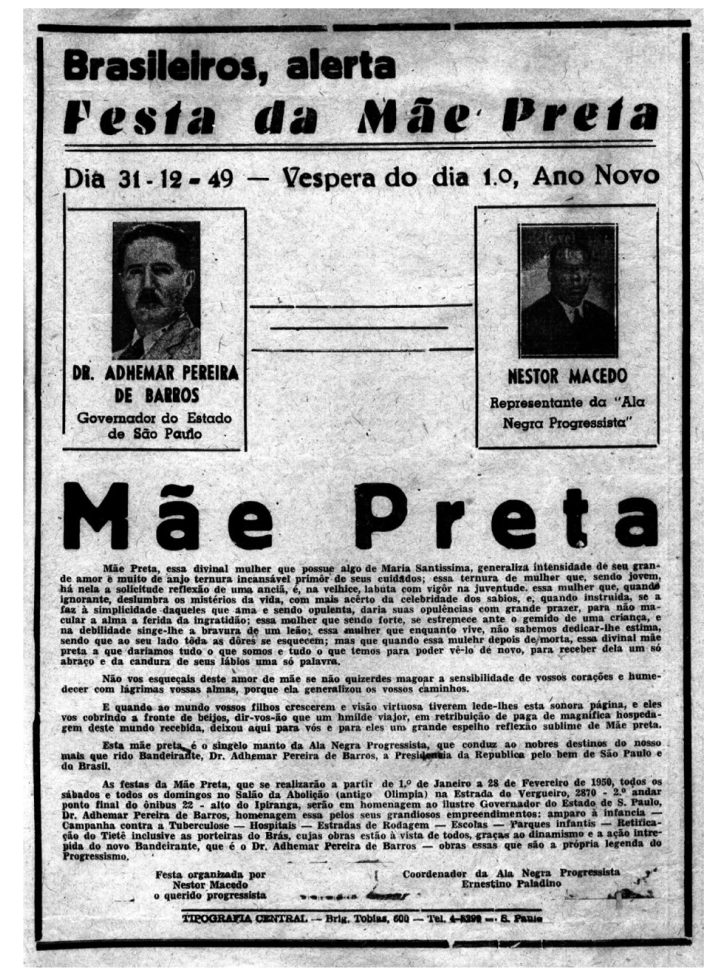

Panfleto "Festa da Mãe Preta". São Paulo, 31 de dezembro de 1949. Confiscado e anexado ao Pront. $n .^{\circ} 1018$. Fundo DEOPS/ SP. APESP.

Exemplo é o panfleto "Festa da Mãe Preta", datado de 31 de dezembro de 1949, ilustrado com as fotografias do Dr. Adhemar Pereira de Barros, governador do Estado de São Paulo, e de Nestor Macedo, Representante da "Ala Negra Progressista", dois ícones da coligação entre o Partido Social Progressista e o Partido Trabalhista Brasileiro, nos anos de 1951. Nestor Macedo atuava como o organizador destas "festas-comícios" direcionadas para a comunidade afro-brasileira e para a propaganda política de alguns candidatos seletos ${ }^{42}$. Este

42 "Mãe Preta". Panfleto do Partido Social Progressista, São Paulo, dezembro de 1949. Pront. 101.018; "Alerta 2 de setembro", Panfleto produzido pela Ala Negra progressista. São Paulo, setembro de 1951. Pront. n. ${ }^{\circ}$ 101.018. DEOPS/SP. APESP. 
impresso reifica o papel dos políticos em ação entre 1930-1954 perpassando pela glorificação de feitos heróicos. Convidava o povo em geral para homenagear o Dr. Adhemar de Barros, o Professor Lino de Mattos, o Coronel Ribamar e os gloriosos paraquedistas da Força Pública de São Paulo, "que tão bem houveram na arrancada humanitária contra as selvas bravias!”. Entre fogos-de-artifício, danças caipira e churrasco de vitela, Lino de Mattos seria aclamado o HERÓI DAS SELVAS, configurando a construção da imagem do salvador. Os documentários cinematográficos e as fotografias de Adhemar, apresentado como a "esperança do povo do Brasil" e de Nestor Macedo, "soldado adhemarista" e representante da Sociedade Ala Negra Adhemarista, funcionam como elo de ligação entre o poder e a comunidade negra, carente de representatividade política. Este processo de heroicização completa-se com a nomeação de Nestor Macedo como "rei popular das organizações" da GRANDIOSAS FESTAS DA CHITA" animadas graças a CARAVANA DE SOLIDARIEDADE HUMANA". 43

Segundo alguns panfletos distribuídos em nome do governo do Estado de São Paulo com o apoio da Ala Negra Progressista, as "festas da Mãe Preta" seriam organizadas para homenagear o ilustre governador Adhemar de Barros [e não Mãe Preta] elogiado por seu dinamismo e por sua ação "intrépida de novo Bandeirante". Antecede esta nomeação um falso discurso composto para sensibilizar a população negra, público-alvo das propostas populistas. Enquanto uma "divina mulher, a Mãe Preta "possue algo de Maia Santíssima" e tem muito de "anjo ternura" e da "bravura de uma leão". ${ }^{4}$

43 "Grandiosas Festas da Chita". Panfleto produzido pelo Grupo Progressista Adhemarista, São Paulo, Junho,1952. Pront. $n .^{\circ} 101.018$. DEOPS/SP. APESP. Ver o importante trabalho desenvolvido por Rodrigo Archangelo, sob o título Um Bandeirante nas Telas de São Paulo: o Discurso Adhemarista em Cinejornais (1946-1956), Dissertação de Mestrado em História Social, FFLCH, Universidade de São Paulo, 2007.

44 "Brasileiros, alerta. Festa da Mãe Preta", Panfleto produzido pela Ala Negra Progressista, São Paulo, janeiro de 1949 , Pront. $n .^{\circ}$ 101018. DEOPS/SP. APESP. 
$\mathrm{Na}$ categoria dos panfletos oficiais, ainda que raros nos arquivos da Polícia Política, identificamos os seguintes estilos ${ }^{45}$ :

- Os constitucionais: dedicados a informar a população sobre os atos do Estado cuja intervenção vem sempre mascarada pelo slogan "a bem do serviço público". Era comum a transcrição na íntegra de decretos-lei como, por exemplo, o Decreto Federal $\mathrm{n}^{\circ} 6.455$ que reconhecia a Associação Paulista de Imprensa como sendo de utilidade pública. ${ }^{46}$

- Os comemorativos: editados com o objetivo de cooptar e/ ou aliciar determinados segmentos da população, como por exemplo, os jovens e as camadas pobres e negras excluídas por sua identidade étnica e/ou política.

- Os combativos: de luta contra o comunismo, apresentado como inimigo $n .^{\circ} 1$ da Nação brasileira, ou contra outros "perigos" reais ou imaginários. Preocupado com a penetração que a ANL vinha alcançando junto ao operariado, o Estado varguista aliado aos grupos de direita resolveu adotar medidas profiláticas de combate ao comunismo. Valendo-se das mesmas táticas de propaganda que seus "inimigos negros e vermelhos", articulou uma contra-propaganda com o objetivo de alertar "os menos avisados" do perigo que os rondava. Nada mais eficiente do que produzir panfletos assinados ou anônimos com mensagens anticomunistas que, agilmente, circulassem nos meios operários e estudantis. Neste "padrão"

\footnotetext{
45 Importante lembrar que a maioria dos panfletos selecionados pelos pesquisadores do PROIN, são impressos que circulavam na clandestinidade e que haviam sido confiscados por representarem um perigo á ordem instituída. No caso de encontrarmos panfletos oficiais anexados aos prontuários temos que avaliar em que condições ele foi parar naquele processo. Geralmente foram encaminhados pelos próprios produtores às autoridades policiais com o propósito de obter autorização para a realização de uma festa ou homenagem públicas.

46 "Associação Paulista de Imprensa". Comunicado da A.P.I., São Paulo, 20 de maio de 1934, Pront. $n .^{\circ}$ 35603. DEOPS/SP. APESP.
} 
de discurso classificamos o panfleto produzido pela liga Anticomunista.

\section{Considerações finais}

Em síntese: cabe aqui reavaliar os mitos políticos como um legado histórico. Herdamos a imagem heróica de Vargas descrito como político extraordinário, figura divina investida de potência transformadora, cujo perfil de ditador foi, ainda nos de 1980, evitado pela historiografia brasileira. Até então reforçou-se o perfil salvacionista de Vargas apresentado como o homem providencial, instaurador de um clima de paz e trabalho no Brasil. Com sabedoria e perspicácia, Vargas (re) elaborou os conteúdos de protestos dos trabalhadores e, através da ideologia do trabalhismo e do populismo, uso-os em benefício próprio garantindo sua permanência no poder até 1945 . Ao tentar subordinar os trabalhadores e evitar suas filiações às ideologias ditas "exóticas", o Estado procurou impor suas versões auxiliado por estratégias de dominação, dentre as quais a propaganda política. É neste contexto que a construção da imagem do imagem do Estado-Providência e entendemos o fortalecimento do mito da outorga da legislação social, elemento sempre presente nos discursos direcionados para o trabalhador nacional.

O trabalho "sujo" de varredura dos inimigos do regime, ficava em segundo plano, protegido pelo secretísmo dos arquivos policiais e diplomáticos vedados à consulta pública até 1995. A propaganda política cumpriu com o seu papel de camuflar o mundo fabricando versões para uma realidade que não convinha vir à superfície: a da realidade das prisões, da violência das deportações, da perda das liberdades individuais, da negação de solidariedade aos judeus perseguidos pelo nazismo e do direito à liberdade de expressão. 